\title{
IMPROVED PHOTOSTABLE FRET-COMPETENT BIARSENICAL- TETRACYSTEINE PROBES BASED ON FLUORINATED FLUORESCEINS
}

\author{
Carla C. Spagnuolo ${ }^{\dagger}$, Rudolf J. Vermeij ${ }^{\dagger}$ and Elizabeth A. Jares-Erijman ${ }^{\dagger}$ \\ †Departamento de Química Orgánica, Facultad de Ciencias Exactas y Naturales, \\ Universidad de Buenos Aires, Argentina. \\ ${ }^{*}$ Department of Molecular Biology, Max Planck Institute for Biophysical Chemistry, \\ 37077 Göttingen, Germany. Present address: MESA+ Institute for Nanotechnology, \\ Biophysical Engineering Group, Faculty of Science and Technology, University of \\ Twente, PO Box 217, 7500 AE Enschede, The Netherlands.
}

* corresponding author

\section{Contents}

1 - Materials

2 - Synthesis of Compounds

3 - Spectroscopic properties

4 - Photostability

5 - FRET

6 - Steady state anisotropy 


\section{1 - Materials}

General Procedures. NMR measurements were carried out on a Bruker $200 \mathrm{MHz}$ AM, $400 \mathrm{MHz}, 500 \mathrm{MHz}$ AMX, Mercury $300 \mathrm{MHz}$ (Varian) or on a INOVA $500 \mathrm{MHz}$ (Varian) NMR spectrometer. Chemical shifts are in ppm (internal reference TMS) and coupling constants are given in $\mathrm{Hz}$.

4-Fluororesorcinol was purchased from CPC Scientific, San Jose, CA, USA and model peptide from WITA GmbH, Germany. All other chemicals were obtained from Aldrich Chem. Co.

Reactions were monitored by thin-layer chromatography on Merck silica gel plates $(60 \mathrm{~F}-$ 254). Column chromatography was performed on silica gel (230-400 mesh, Merck ASTM) or on Florisil ${ }^{\circledR}$ (60-100 mesh, J.T.Baker).

ESI and HRMS were measured on an APEX IV 7 Tesla-Fourier Transform Ion Cyclotron Resonance (FTICR)- Mass spectrometer (Bruker) or on a TSQ 7000 Triple-StageQuadrupol-Instrument (Finnigan) with Electrospray-Ionisation, at the Georg-AugustUniversity of Goettingen, Germany.

Absorption and fluorescence spectra were measured with a UVIKON 943 Double Beam UV/Vis absorption spectrophotometer and with a Perkin Elmer LS50B fluorescence spectrophotometer, respectively. Lifetime measurements were made by TCSPC in a Horiba Jobin Yvon IBH Fluorescence Lifetime Spectrometer System. The excitation source at $495 \mathrm{~nm}$ was a NanoLED N-01 Aqua and the detection module was TBX-04-A. Irradiation was carried out using a Superlite SUV-DC-P system incorporating a 200W DC Super-Pressure short arc lamp coupled to a light guide for high UV transmission and an electronic timer for exposure time control (Lumatec $\mathrm{GmbH}$, Munich, Germany). Output light was passed through a band-pass filter Schott BG18. 


\section{2 - Synthetic Methods}

\section{General Synthesis of Biarsenical Derivatives.}

3,4,5,6-Tetrafluorofluorescein, 2',7'-difluorofluorescein and FlAsH derivatives were prepared according to published procedures ${ }^{1,2}$.

Fluorescein-4',5'-bis(mercuric diacetate). Fluorescein (1 g, $3 \mathrm{mmol}$ ) was added to a stirred solution of $\mathrm{HgO}(2.6 \mathrm{~g}, 12 \mathrm{mmol})$ in trifluoroacetic acid $(40 \mathrm{~mL})$. The reaction was mantained at room temperature overnight, added to water and the precipitate was collected by filtration, washed with water, and dried in vacuo over $\mathrm{P}_{2} \mathrm{O}_{5}$ to yield $2.5 \mathrm{~g}$ $(87 \%)$ of a red solid. The crude product was used without further purification.

2',7'-Difluorofluorescein-4',5'-bis(mercuric diacetate). 2',7'-Difluorofluorescein (0.3 g, $0.8 \mathrm{mmol})$ was added to a stirred solution of $\mathrm{HgO}(0.37 \mathrm{~g}, 1.7 \mathrm{mmol})$ in trifluoroacetic acid $(6.5 \mathrm{~mL})$. The reaction mixture was kept at room temperature overnight, added to water and the precipitate was collected by filtration and dried in vacuo over $\mathrm{P}_{2} \mathrm{O}_{5}$ to yield $0.65 \mathrm{~g}(80 \%)$ of a red solid. The crude product was used without further purification.

\section{3,4,5,6-Tetrafluorofluorescein-4',5'-bis(mercuric diacetate). 3,4,5,6-}

Tetrafluorofluorescein $(0.5 \mathrm{~g}, 1.1 \mathrm{mmol})$ was added to a stirred solution of $\mathrm{HgO}(0.52 \mathrm{~g}$,

$2.4 \mathrm{mmol})$ in trifluoroacetic acid $(9 \mathrm{~mL})$. The reaction was mantained at room

temperature overnight, the precipitate was collected by filtration and dried in vacuo over

$\mathrm{P}_{2} \mathrm{O}_{5}$ to yield $1.10 \mathrm{~g}(95 \%)$ of an orange powder. The crude product was used without further purification.

4',5'-Bis(1,2,3-dithioarsolan-2-yl)-fluorescein, FIAsH-EDT ${ }_{2}$. Crude fluorescein-4',5'bis(mercuric trifluoroacetate) $(92 \mathrm{mg}, 0.1 \mathrm{mmol})$ was suspended in dry NMP $(1.5 \mathrm{~mL})$ under $\mathrm{Ar}$ and treated with arsenic trichloride $(0.16 \mathrm{~mL}, 2.0 \mathrm{mmol})$, Diisopropylethylamine $(0.14 \mathrm{~mL}, 0.80 \mathrm{mmol})$, and palladium(II) acetate $(1 \mathrm{mg})$. The reaction mixture was kept overnight at room temperature and poured on aqueous phosphate buffer, $\mathrm{pH} 7$ : acetone (1:1 v/v $\left.50 \mathrm{~mL}, 0.25 \mathrm{M} \mathrm{K}_{2} \mathrm{HPO}_{4}\right)$, stirred for $5 \mathrm{~min}$, and ethanedithiol $(0.5 \mathrm{~mL})$ was added. After 20 min of stirring, $\mathrm{CHCl}_{3}(30 \mathrm{~mL})$ was added, and the mixture was stirred for $1 \mathrm{~h}$ before the phases were separated. The aqueous layer was extracted $(2 \times 30 \mathrm{~mL})$ with $\mathrm{CHCl}_{3}$. The combined organic layers were dried over $\mathrm{Na}_{2} \mathrm{SO}_{4}$ and evaporated to dryness. The orange residue was purified by chromatography 
on Silica Gel (Packed in with $\mathrm{CHCl}_{3}-0.5 \%$ HOAc, sample loaded in $\mathrm{CHCl}_{3}$ ) with elution from $0.5 \% \mathrm{HOAc}_{-} \mathrm{CHCl}_{3}$ to ethyl acetate- $0.5 \% \mathrm{HOAc}$. The combined fractions were concentrated and subjected to trituration with $\mathrm{EtOH}-\mathrm{H}_{2} \mathrm{O}$. $22.5 \mathrm{mg}$ ( $34 \%$ yield) of a whitish-pink solid was obtained. ${ }^{1} \mathrm{H}-\mathrm{NMR}\left(\mathrm{CDCl}_{3}-\mathrm{CD}_{3} \mathrm{OD}\right.$ 1:1, ppm): $3.54(8 \mathrm{H}, \mathrm{m}$, partially obscured by solvent), 6.49 (d, $2 \mathrm{H}, J=9.0 \mathrm{~Hz}), 6.62$ (d, 2H, $J=9 \mathrm{~Hz}), 7.20$ (d, $J$ $=6 \mathrm{~Hz}, \mathrm{H}-6), 7.65$ (dd, $J=6$ and $2 \mathrm{~Hz}, \mathrm{H}-4,5$ ), 8.00 (d, $J=6 \mathrm{~Hz}, \mathrm{H}-3)$. ESI-HRMS: $[\mathrm{M}+\mathrm{H}]^{+}:$664.8541. Calcd for $\left(\mathrm{C}_{24} \mathrm{H}_{19} \mathrm{O}_{5} \mathrm{As}_{2} \mathrm{~S}_{4}\right)^{+}: 663.8547$.

4',5'-Bis(1,2,3-dithioarsolan-2-yl)-2',7'-difluorofluorescein, F2-FIAsH-EDT $2 . \quad$ Crude 2',7'-difluorofluorescein-4',5'-bis(mercuric trifluoroacetate) $\left(\begin{array}{llll}0.2 & \mathrm{~g}, & 0.2 \mathrm{mmol}) & \text { was }\end{array}\right.$ suspended in dry NMP $(3.0 \mathrm{~mL})$ under Ar and treated with arsenic trichloride $(0.34 \mathrm{~mL}$, $4.0 \mathrm{mmol})$, DIPEA (0.28 mL, $1.6 \mathrm{mmol})$, and palladium(II) acetate $(1 \mathrm{mg})$, following the procedure described above. Purification was carried out by column chromatography on Florisil ${ }^{\circledR}$, eluted with $\mathrm{CH}_{2} \mathrm{Cl}_{2}-0.5 \%$ HOAc gradient up to AcOEt- $0.5 \%$ HOAc. The combined fractions were concentrated and subjected to trituration with $\mathrm{EtOH}-\mathrm{H}_{2} \mathrm{O}$. 13.4 $\mathrm{mg}(9.8 \%$ yield $)$ of an orange solid was obtained. ${ }^{1} \mathrm{H}-\mathrm{NMR}\left(\mathrm{CDCl}_{3}, \mathrm{ppm}\right): 3.61(\mathrm{~m}, 8 \mathrm{H})$, $6.42(\mathrm{~d}, 2 \mathrm{H}, J=10 \mathrm{~Hz}$ ), 7.21 (d, 1H, $J=5 \mathrm{~Hz}, \mathrm{H}-3), 7.65-7.74$ (m, 2H, H-4, 5), 8.03 $(\mathrm{d}, 1 \mathrm{H}, J=5 \mathrm{~Hz}, \mathrm{H}-6)$. ES-HRMS $[\mathrm{M}+\mathrm{H}]^{+}:$700.8358. Calcd for $\left(\mathrm{C}_{24} \mathrm{H}_{17} \mathrm{~F}_{2} \mathrm{O}_{5} \mathrm{As}_{2} \mathrm{~S}_{4}\right)^{+}$: 700.8358 .

4',5'-Bis(1,2,3-dithioarsolan-2-yl)-3,4,5,6-tetrafluorofluorescein, F4-Flash-EDT ${ }_{2}$. Crude 3,4,5,6-tetrafluorofluorescein-4',5'-bis(mercuric trifluoroacetate) (0.3 g, $0.3 \mathrm{mmol})$ was suspended in dry NMP $(3 \mathrm{~mL})$ under Ar and treated with arsenic trichloride $(0.5 \mathrm{~mL}$, $3.0 \mathrm{mmol})$, DIPEA $(0.4 \mathrm{~mL}, 2.4 \mathrm{mmol})$, and palladium(II) acetate $(1 \mathrm{mg})$, following the procedure described above. Purification was carried out by chromatography on Florisil®, eluted with $\mathrm{CH}_{2} \mathrm{Cl}_{2}-0.5 \% \mathrm{HAcO}$ gradient up to AcOEt- $0.5 \% \mathrm{HAcO}$. The combined fractions were concentrated and subjected to trituration with EtOH- $\mathrm{H}_{2} \mathrm{O} .{ }^{1} \mathrm{H}-\mathrm{NMR}$ $\left(\mathrm{CDCl}_{3}-\mathrm{CD}_{3} \mathrm{OD}, 1: 1, \mathrm{ppm}\right): 3.49$ (m, 8H partially obscured by solvent), 7.06 (d, 2H, $J=$ $8.6 \mathrm{~Hz}), 7.25(\mathrm{~d}, 2 \mathrm{H}, J=8.6 \mathrm{~Hz})$. ES-HRMS: $[\mathrm{M}+\mathrm{H}]^{+}:$736.8168. Calcd for $\left(\mathrm{C}_{25} \mathrm{H}_{15} \mathrm{As}_{2} \mathrm{~F}_{5} \mathrm{O}_{5} \mathrm{~S}_{4}\right)^{+}: 736.8170$. 

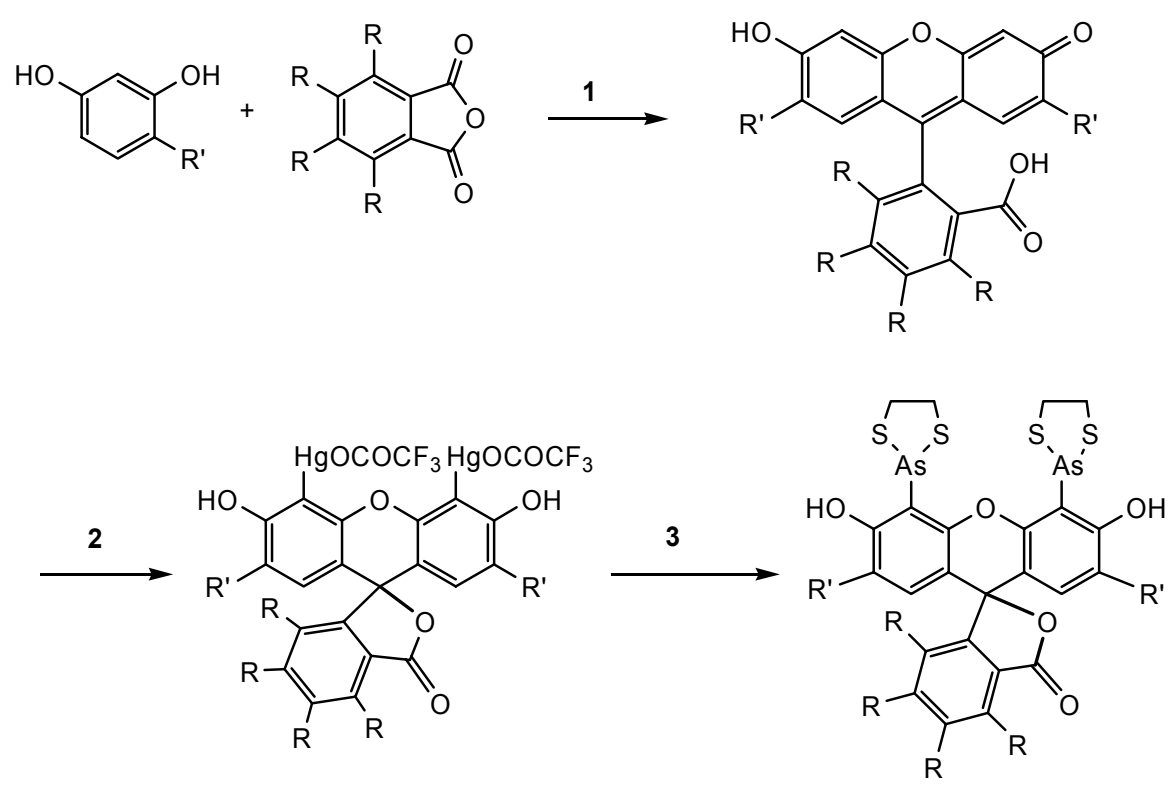

F2FlAsH, R = H, R' = F; F4FlAsH, R = F, R' = H

1- $\mathrm{CH}_{3} \mathrm{SO}_{3} \mathrm{H}, 80-85^{\circ} \mathrm{C}, 48 \mathrm{~h}$

2- $\mathrm{HgO}, \mathrm{TFA}$, r.t., $12 \mathrm{~h}$

3- i) $\mathrm{AsCl}_{3}$, DIPEA, $\mathrm{Pd}(\mathrm{AcO})_{2}$, NMP; r.t., overnight; ii) $\mathrm{K}_{2} \mathrm{HPO}_{4} 1.4 \mathrm{M}$ : Acetone (1:1), EDT 


\section{3 - Spectroscopic Properties}

\section{1- In vitro labeling of a model peptide with fluorinated FlAsH derivatives}

The model target peptide P12 (FLNCCPGCCMEP) in buffer Na-Hepes 20 mM, 1 mM 2Mercaptoethanol, $10 \mathrm{mM}$ TCEP, $\mathrm{pH} 7.4$, was added to a $0.1 \mu \mathrm{M}$ solution of the biarsenical compound in the same buffer, to a final concentration of $1 \mu \mathrm{M}$. Emission spectra were taken after two hours. Fig. 2, left pannel depicts the emission spectra of the F2FlAsH-P12, F4F1AsH-P12 and F1AsH-P12 at equal concentration. A 4-fold enhanced fluorescence emission of F2F1AsH compared to F1AsH can be observed, corresponding to a two fold increase in Molar extinction coefficient and a two fold increase in fluorescence quantum yield.

\section{2- Absorption spectra of biarsenical compounds and $\mathrm{pH}$ dependence in the physiological range}

The absorption spectra of $20 \mu \mathrm{M}$ solutions of F2F1AsH, F4FlAsH and FlAsH-EDT 2 , in $20 \mathrm{mM}$ phosphate buffer, at different $\mathrm{pH}$ values, are shown in Figure $\mathrm{S} 1$. In all cases, the absorbance and the corresponding emission, increases with the increase of $\mathrm{pH}$. 

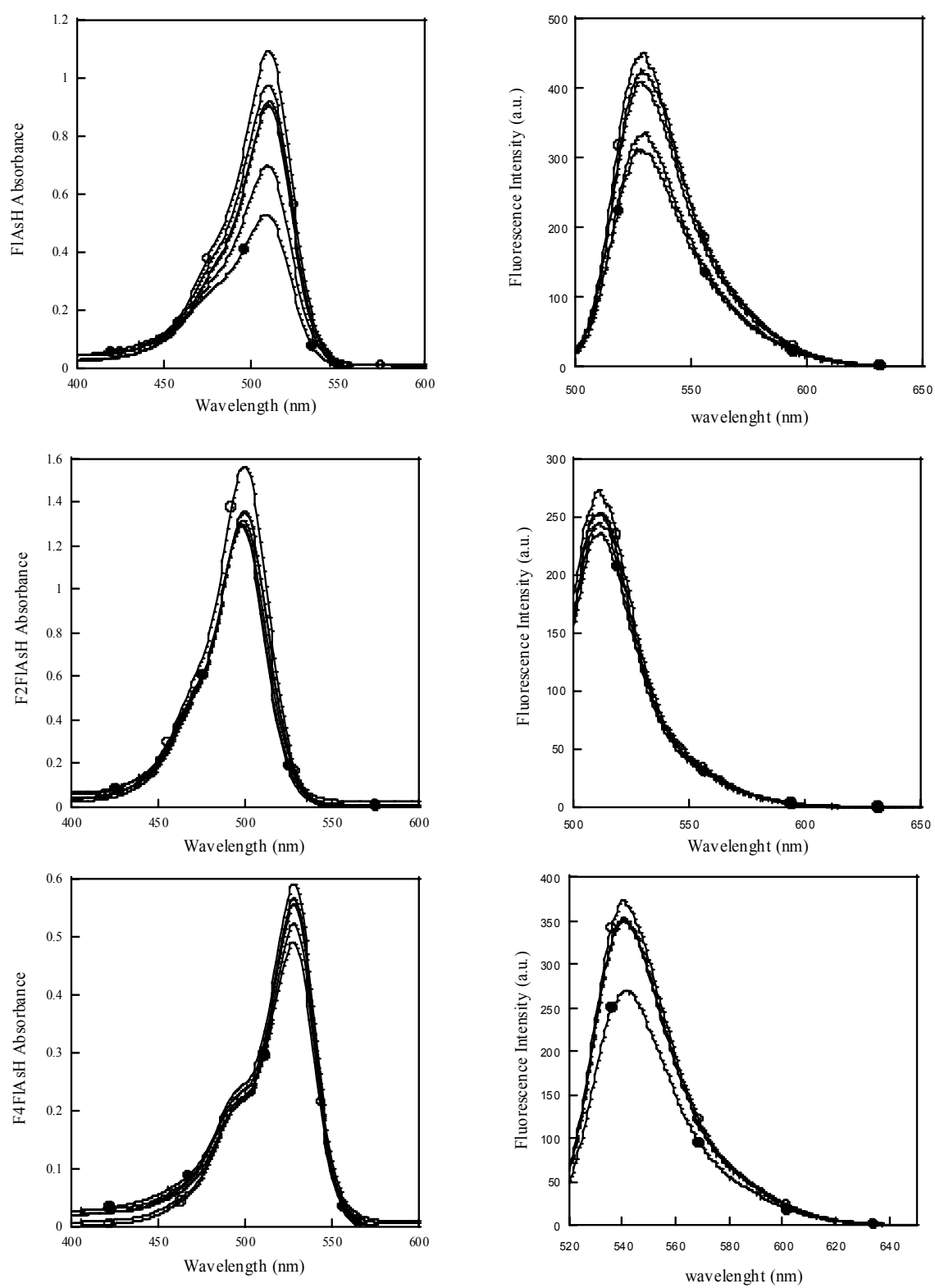

Figure S1. Dependence of the absorption (left panel) and emission (right panel) properties within the physiological $\mathrm{pH}$ range $(5.7-7.8)$. In all plots: $\bullet$ initial, $\bigcirc$ final.

\section{3- Fluorescence lifetimes}

The fluorescence lifetimes of the complexes obtained as described in section 3.1, were determined by TCSPC. The corresponding values for each parent fluorescein were also determined in $20 \mathrm{mM}$ buffer HEPES, pH 7.4 for comparison. 


\begin{tabular}{|c|c|c|c|}
\hline P12-Complex & t (ns) & Fluorophore & t (ns) \\
\hline FlAsH & 4.88 & Fluorescein & 4.07 \\
\hline F2FlAsH & 4.78 & $2^{\prime}, 7^{\prime}$-Difluorofluorescein & 4.02 \\
\hline F4FlAsH & 5.18 & 3,4,5,6-Tetrafluorofluorescein & 4.13 \\
\hline
\end{tabular}

\section{4- Photostability}

Samples containing $10 \mu \mathrm{M}$ of the biarsenical compounds and $10 \mu \mathrm{M}$ of the model peptide P12, were incubated at room temperature for $1 \mathrm{~h}$. Each solution of the FlAsH-peptide complex was irradiated for $120 \mathrm{~min}$ as previously described (see General Procedures). Values of $k_{b l}$ were calculated from the monoexponential fitting of the experimental photobleaching decay, according to the model described in (Eq. 1) for the intermediate irradiation regime. ${ }^{3}$

$$
\mathrm{k}_{\mathrm{fit}}=\mathrm{k}_{\mathrm{bl}} \cdot \tau \cdot \psi \cdot \sigma \cdot \mathrm{t}
$$

where $\tau(\mathrm{s})$ is the lifetime, $\psi$ is the irradiance (photons $\mathrm{cm}^{-2} \mathrm{~s}^{-1}$ ) and $\sigma$ is the molecular absorption cross-section $\left(\mathrm{cm}^{2}\right.$ molecule $\left.{ }^{-1}\right)$. Inasmuch as a broad excitation bandwidth was used, $\sigma$ was computed as a mean value over the spectral distribution function of photon flux and corrected by the spectral integral with the corresponding absorption spectra, including the irradiation source and filter. 

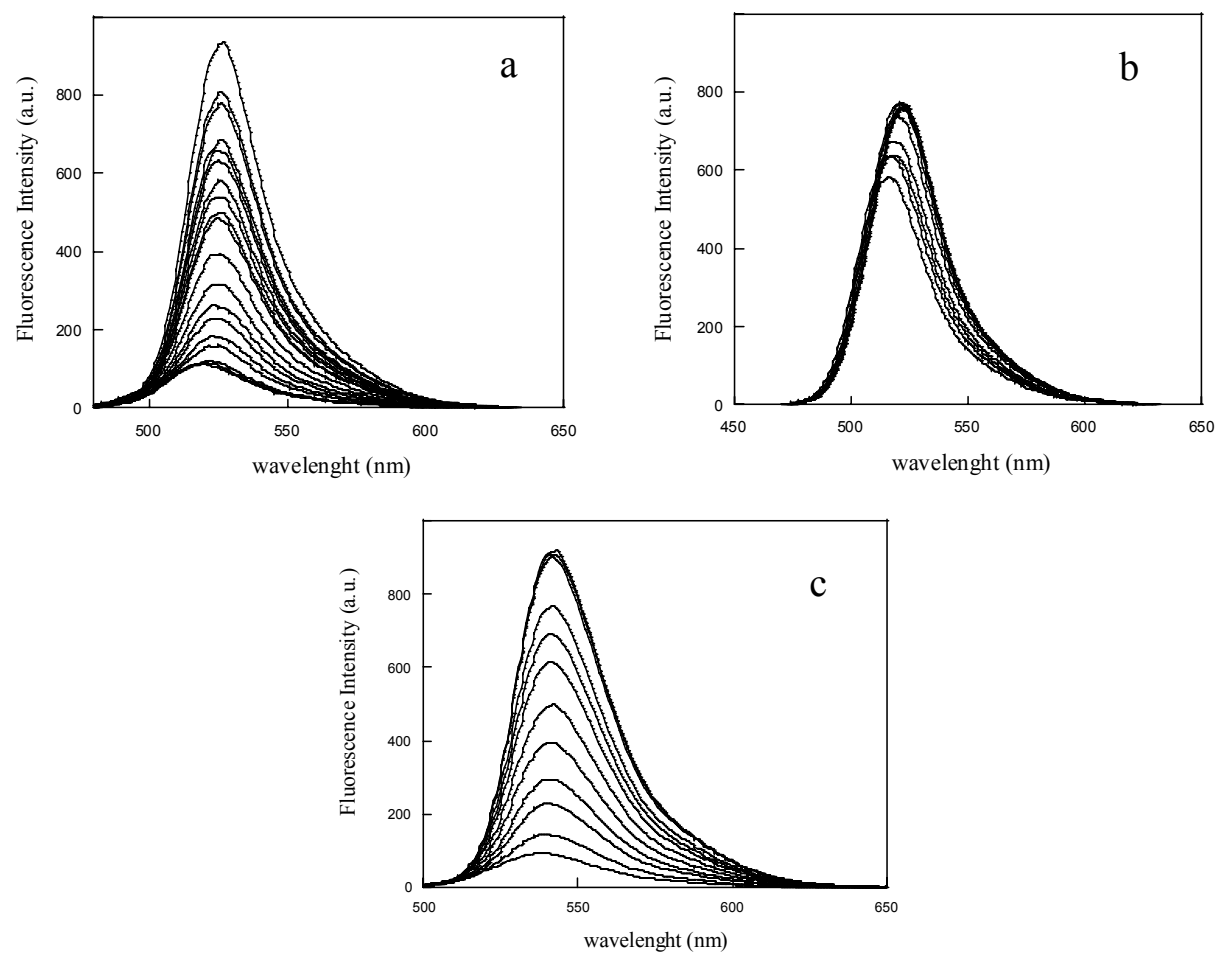

Figure S2. Photobleaching recorded during $120 \mathrm{~min}$ of irradiation and monitored by fluorescence emission. $\lambda_{\text {exc }} 490$ nm. a. FlAsH-P12; b. F2F1AsH-P12; c. F4FlAsH-P12.

Photobleaching of F2FlAsH, F4FlAsH and FlAsH complexes with P12 lead to a residual fluorescence with maxima at 516, 538 and $519 \mathrm{~nm}$, respectively.

\section{5 - FRET determinations}

A $0.8 \mu \mathrm{M}$ solution in $20 \mathrm{mM}$ HEPES, $0.1 \mathrm{M} \mathrm{NaCl}, 1 \mathrm{mM}$ 2-Mercaptoethanol, $\mathrm{pH} 7.4$ of the complex F2F1AsH-P12-biotin was incubated with an equimolar solution of streptavidin and titrated with increasing amounts of F4F1AsH-P12-biotin in a quartz cuvette equipped with a magnetic stirrer.

Each addition was followed by measurement of the emission intensity using $490 \mathrm{~nm}$ as the excitation wavelength.

\section{FRET calculations}

$R_{o}$, the critical Förster distance for 50\% FRET efficiency, is defined by $R_{o}^{6}=8.785 \cdot 10^{-5} \kappa^{2} \Phi_{D} J n^{-4}$ units, $\mathrm{nm}^{6}$ ) where $\Phi_{D}$ is the quantum yield of the donor in the 
absence of acceptor, $n$ is the refractive index of the medium (taken to be 1.33 for water), $\kappa^{2}$ is the orientation factor between donor and acceptor (here assumed to be $2 / 3$, the value corresponding to rapid and isotropic reorientation of donor and acceptor during the excited state), and $J$ is the spectral overlap integral between donor and acceptor, given by $J=\int F_{\lambda}^{D} \varepsilon_{\lambda}^{A} \lambda^{4} d \lambda$, where $F_{\lambda}$ is the normalized donor fluorescence spectrum and $\varepsilon_{\lambda}$ is the wavelength-dependent molar extinction coefficient $\left(\mathrm{M}^{-1} \mathrm{~cm}^{-1}\right)$ of the acceptor. For an isolated donor-acceptor pair separated by $r_{D A}$, the FRET efficiency $E$ varies according to $E=\left[1+\left(r_{D A} / R_{o}\right)^{6}\right]^{-1}$.

\section{6 - Steady state anisotropy}

Steady state emission anisotropy of $1 \mu \mathrm{M}$ solutions of F2FlAsH-P12-biotin and F4FlAsH-P12-biotin in $20 \mathrm{mM}$ HEPES, $0.1 \mathrm{M} \mathrm{NaCl}, 1 \mathrm{mM}$ 2-ME, $\mathrm{pH} 7.4$ was determined according to eq. 2 , were $\mathrm{G}$ is the correction factor for the bias in the detection of the two polarized components $I_{\|,} I_{\perp}$

$$
r=\frac{\left(I_{\|} / I_{\perp}\right)-G}{I_{\|} / I_{\perp}+2 G}
$$

Eq.2

\section{Safety cautions}

Appropriate methods for handling reagents shall be considered when carrying out the described reactions. All reactions should be carried out in a fume hood with an appropriate disposal of residues. The heterocyclic aromatic organomercurials prepared in this work were nonvolatile and either slightly soluble or practically insoluble in common solvents, hence they were probably less hazardous than e.g. many aliphatic organomercurials.

\section{References}

1- Sun, W. C.; Gee, K. R.; Klaubert, D. H.; Haugland, R. P., Synthesis of fluorinated fluoresceins. J. Org. Chem. 1997, 62, (19), 6469-6475.

2 - Adams, S. R.; Campbell, R. E.; Gross, L. A.; Martin, B. R.; Walkup, G. K.; Yao, Y.; Llopis, J.; Tsien, R. Y., New biarsenical Ligands and tetracysteine motifs for protein labeling in vitro and in vivo: Synthesis and biological applications. J. Am. Chem. Soc. 2002, 124, (21), 6063-6076. 
3 - Jovin, T. M.; Arndt-Jovin, D. J.; Marriott, G.; Clegg, R. M.; Robert-Nicaud, M.; Schormann, T. Optical Microscopy for Biology 1990, 575-602. 